\title{
Management of investment processes in social capital: A conceptual approach to assessment
}

\author{
Karina Nemashkalo ${ }^{1}$, Olga Myronova ${ }^{1}$, Denys Kipa ${ }^{1}$ \\ ${ }^{I}$ Department of Management and Business, Simon Kuznets Kharkiv National University of Economics
}

\begin{tabular}{|c|c|}
\hline Article Info & ABSTRACT \\
\hline Received Dec 20, 2018 & $\begin{array}{l}\text { Any social problems need to be solved first of all by investment methods: creating } \\
\text { new jobs (innovative training and retraining of employees), increasing labor } \\
\text { productivity and increasing real wages, and raising the economic interest of employees } \\
\text { and entrepreneurs in the highly efficient use of accumulated total human capital (the } \\
\text { life quality improving). These methods should contribute raising the level of trust in } \\
\text { society. Due to the generalization of theoretical and practical studies, the classification }\end{array}$ \\
\hline Keyword: & $\begin{array}{l}\text { of income types from accumulation into social capital, conditions and causes of its } \\
\text { formation are generalized. It is determined that management of investment processes in } \\
\text { social capital is impossible without qualitative and quantitative assessment of }\end{array}$ \\
\hline Social capital & investments. The comprehensive system of social investment assessment at the macro-, \\
\hline Human capital & meso- and microeconomic levels is presented. A quantitative aspect of this system \\
\hline Social investments & $\begin{array}{l}\text { involves a direct assessment of the enterprises financial costs in the region for social } \\
\text { programs and initiatives. The qualitative aspect is related to the assessment of the }\end{array}$ \\
\hline Assessment & completeness and complexity degree of the investment process. The given system of \\
\hline Management. & $\begin{array}{l}\text { assessment will allow identifying the main problems in the social investment } \\
\text { management. }\end{array}$ \\
\hline
\end{tabular}

\section{Corresponding Author:}

Olga Myronova, Department of Management and Business,

Simon Kuznets Kharkiv National University of Economics

9-A Nauka ave., Kharkiv, 61166, Ukraine

Email: olga_myronova@ukr.net

\section{Introduction}

It becomes increasingly clear that social investments play an vital role in society, because their volume significantly influences the level and quality of life of the population. This is evidenced by the steady growth of investment volumes in the Ukrainian economy. According to the World Bank, 2018 [24], current investment projects in Ukraine amount to approximately $\$ 2,5$ billion.

According to the UN, in 2016 the organizations of the UN system mobilized \$212,5 million for the purpose of assistance to Ukraine, of which $\$ 70$ million were mobilized by the UNDP. By resources volumes and project portfolio the UNDP program activity in Ukraine is one of the largest in the region of Europe. In 2017, the UN organizations raised \$269,3 million for the purpose of assistance to Ukraine, of which $\$ 80$ million is a part of the United Nations Development Program [16] (Klympush-Tsyntsadze, 2017). Increasing the share of investing in the Ukrainian economy suggests the emergence of need to manage this process ensuring effective economic development.

World and domestic experience shows that for economic recovery in the country, along with investments in physical capital, large-scale investments in education, health [27], culture and other components of human capital are required, increasing confidence in the government, that is, increasing social capital. This tendency is illustrated in [11], where investments in social sphere increased approximately twice.

In addition, Patnem, 1996 in [21] showed that the solution to many macroeconomic problems, such as poverty, high unemployment, and the development of education and healthcare, is more effective if public 
organizations and civil society institutions are involved, because in this case the implementation of social norms is stabilized.

The relevance of the study of regulation of the social capital investment processes is related to the need to develop methodical support for social investment, the importance of which is significantly increasing for the successful economic development in the transition to a post-industrial society.

Therefore, the goal will be to further develop the theoretical statements and methodological provisions for managing investment in social sphere. Many ukrainian and foreign scholars are engaged in the development of social capital in ukrainian and foreign literature, such as: Hrishnova, Polyviana, 2009 in [13]; Hryshova, Shabatura, 2014 in [14]; Bova, 2003 in [5]; Patnem, 1996 in [21]; Bourdieu, 1993 in [3]; Coleman, 1990 in [6]; Fukuyama, 2002 in [8]; Glaeser, et al., in 2012 [9].

Problems of social investments are investigated in the works of such scholars as: Veretennykova, 2013 in [25]; Voloshchuk, 2013 in [26]; Halushka, 2012 in [12]; Kuzhel, 2015 in [18]; Melnychuk, 2016 in [19]; Nadraha, 2014 in [20]; Yazliuk, 2014 in [28]; Babenko, et al., 2018 in [1] and many others.

For effective policy and investment in social sphere, it is necessary to monitor the quantitative and qualitative dynamics of the social capital. Therefore, there is an urgent need to manage investment in social sphere at all stages of its accumulation in order to develop scientifically-based recommendations for the preservation of already accumulated social capital and regarding opportunities for its further growth.

\section{Sosial capital descripion}

\subsection{Features of capital forms about investing}

Consideration of the social capital as a flow [9] (Glaeser, et al., 2012) makes it possible to conclude that social connections arranged by the individual can also be considered as a stock that is formed by investments and brings returns, therefore, serves as a capital in its social form. Thus, according to P. Bourdieu, 1993 in [3], the social capital is an "ensemble of invisible ties" that form a "space of positions external to each other, defined one through others, in their proximity, neighborhood or distance between them, as well as by their relative position: above, below or between, in the middle". The tool for determining the position of the individual in the social space is a peculiar system of coordinates, which includes: the relation of a person to certain social groups; the relation of these groups to each other within the community; the relation of this community to others. Consequently, the social space is multidimensional, and the social position of an individual is a combination of the relationships of the individual with all groups of the population and their individual members; a set of its statuses.

Bourdieu, 1993 in [3] proved that the social capital is indeed a capital, since, on the one hand, it requires investment for its formation, and on the other hand it brings a return. Moreover, the return on social capital is completely material and expressed in the power "which is given by the possession of various types of capital", and it "is reversed into the assigned physical space in the form of spatial distribution of possession and availability of scarce goods and services, private or public".

Individuals can rationally invest in social capital, their friendship or acquaintanceship is a possible option for such kind of investment. It is needed to know that social capital is a public good, so most part of social funds faces a lack of investment (Table 1).

Table 1. Characteristics of capital forms about investing

\begin{tabular}{clll}
\hline Form of capital & Incentives for investment & Motivation for investment & Type of good \\
\hline Financial & Strong incentive & Personal benefit & Private \\
Human & Strong incentive & Personal benefit & Private \\
Social & Lack of incentive & Public benefit & Public \\
\hline
\end{tabular}

However, in order for the common good to become a capital, investments are necessary.

Coleman, 1990 in [6] mostly considers social capital as a tool for achieving certain goals. Bourdieu, 2001 in [4]; Knack, 2002 in [17]; Shikhirev, 2003 in [23]; Fukuyama, 2004 in [8] emphasize collective efforts of individuals to achieve non-monetary goals as well as beauty, justice, commonwealth, love, and brotherhood. This approach differs from the previous (considering social capital as a tool) and represents an investment in achieving individual and group unity. Great importance is attached to "social energy" in the different forms. For example, a friendship, shared ideals and ideas. They exceed rational own interest and market agreements 
and promote social cooperation. Whatever the incentive for cooperation and trust, investing in individual and group unity can lead to the creation of close social ties with higher economic and social results. Thus, public participation, honesty and social trust can strengthen one another.

Economic literature introduces the precondition that people, when interacting with one another, seek to maximize individual utility and use the resources of social capital when implementing various types of activity. In this approach, the emphasis is focused on the individual's investment strategies in the context of alternative opportunities for using time.

Social capital makes it easier for individuals, groups and communities to solve collective problems. The rules of mutual responsibility and interconnection help ensuring compliance of the behavior with the team requirements. In the absence of trust and interconnections that are provided by mutual actions, individuals will not cooperate, because there will be no confidence in similar behavior of other participants. Social capital can be a side product of various types of activities carried out without the intention of increasing social capital.

Hence, there is a risk of underinvestment, as the participants do not receive and do not fully realize their benefits. As Coleman, 1990 in [6] pointed out, "as a result, there is an imbalance in the society between investments in the organizations, which produce goods on the market and in the organizations (usually voluntary associations), which do not bring benefits". However, getting the information and impact through social relationships can bring private benefits to individuals and in some cases can be used by individuals or groups to exclude outsiders and enhance their domination and privileges.

Thus, the term of "social capital" is based on the idea of the expected return on investment in social relations. Individuals enter into social relations and are included in certain networks for profit. The basis of profit can be, at least, the four most important resources that arise or increase precisely due to social connections and allow increasing the efficiency of economic activity. First, it is an access to information. For ordinary market relations, imperfect information is typical, that is, its secrecy, inaccessibility, unilaterality and, therefore, high costs for obtaining complete, reliable and objective information. Social connections in a particular environment and at certain hierarchical levels (which have the most complete information about current needs and market development prospects) provide the individual with useful information that is not available from other sources, about the opportunities and options for the most profitable behavior on the market. Similarly, social relationships can provide information (both on the consumer and the production market) to organizations, agents, or even the community about the characteristics and properties of an individual that would otherwise have remained unnoticed. This information allows the firm to reduce transaction costs when hiring the best employee from the point of view of his/her qualification, professional and general training, and the employee to find a firm where his/her knowledge and experience are most fully applied and highly appreciated.

\subsection{Social capital investments on the differnet levels of economy}

In the transition from reviewing social capital at an individual level to more complex levels (local community, organizations, society institutions), there is inevitably a problem of increasing the risk of reducing the return on private investment in social sphere.

Investments in social capital represent all kinds of property and intellectual values that are invested in objects of entrepreneurial activity and other kinds of activity, resulting in the creation of profit / social rent (income for example, by reducing transaction costs) or achievement of the social effect. Investments in social capital are connected with the formation of norms and values, behavior patterns, and trust in order to improve the life quality and the society welfare. That is, investment in the capital of social sphere contributes to its accumulation.

A generalization of the comparison of the social capital accumulation and its return on the micro-, meso-, macroeconomic levels is presented in Table 2 .

The participation of a business in the life of a society is either strictly regulated within the framework of existing commercial, tax, labor and environmental legislation or carried out independently under the influence of specially created incentives and privileges. In the first case, the state establishes a "corridor of interaction" between business and society, in which state mechanisms, along with civil structures, create the necessary conditions for business participation in society. In the second case, the state, under the pressure of civilian initiatives, creates effective mechanisms for stimulating business to contribute to social development.

Thus, an effective structure of community management at the meso- and macro levels is achieved, in which the roles of individual parties, their participation and interaction is clearly established. The trends of world 
development require a revision of the benchmarks of our country reforming: in today's economy it is impossible to achieve high production results, saving on social programs, the development of industries that form the processes of human capital reproduction, because the quality of economic growth is determined by its social orientation.

Table 2. Comparison of the social capital accumulation costs and income at the expense of investment

Levels of social
capital Costs in the process of accumulation Return on social capital

Social capital of Costs for the formation and maintenance Reducing social vulnerability

the microeconomic of personal relations; costs associated

level with strengthening their own position in

the group.

Costs for the formation of a local Reducing transaction costs

institutional environment

Costs for entering an existing local Reducing production costs due to the Social capital of group and for fulfilling the obligations privileged access to certain resources; the mesoeconomic set by the members of this group; costs reducing transaction costs by getting an level for development of norms operating in access to the information and resources; this group; costs for the formation of reducing costs for coordination of joint cooperative relations activity; labor productivity growth

Costs for formal and informal mastering Reducing transaction costs for interaction in the community; the costs for creating with counterparties; facilitating access to a climate of trust and an appropriate information of different kinds, connected institutional environment within the with the reduction of bureaucratic barriers; entire society increasing trust in state institutions, consolidation of society; improving the investment climate; growth of social

Social capital of

the

macroeconomic

level stability and economic development; economic progress

Costs for the formation of the national The growth of the global economic institutional environment, which makes relations efficiency

it possible to take an active part in

foreign economic relations

\section{Results}

\subsection{Types of income from the social capital accumulation}

According to the World Bank, 2018 in [24] social investment in 2017 amounted to 10,4 trillion US dollars. Given that the return on investments in the field of human capital formation and accumulation extends to enterprises, households and society as a whole, financing of such investments should be made from different sources at the expense of economically justified investments of interested investors.

Transformations in the social sphere should be aimed at achieving the following main goals:

first, ensuring the most effective protection of socially vulnerable households, because they do not have the opportunity to independently solve social problems and therefore objectively need the state support;

second, ensuring universal availability and socially acceptable quality of basic social benefits, which include, first of all, medical care and general education;

third, creating economic conditions for an able-bodied population that allow citizens at their own expense to provide a higher level of social consumption, including comfortable housing, better quality of education and health services, decent living standards in the elderly;

fourth, forming institutions in the socio-cultural sphere that create an opportunity to maximize the full mobilization of the funds of the population and enterprises, the effective use of these funds, and on this basis 
ensuring the high quality and opportunities of a wide choice of social benefits and services provided to the population.

The analysis of scientific results by Bova, 2003 in [5]; Knack, 2002 in [17]; Shikhirev, 2003 in [23]; Hrytsaienko, Hrytsaienko, 2018 in [15] allowed to classify the types of income from investing in social capital, the conditions and reasons for its formation for each level of the social capital socialization (Table 3 ).

Table 3. Classification of types of income from the social capital accumulation

\begin{tabular}{|c|c|c|c|c|}
\hline Income & Level & Source & Conditions & Reason \\
\hline $\begin{array}{l}\text { Income from } \\
\text { the social } \\
\text { capital } \\
\text { accumulation } \\
\text { at the macro- } \\
\text { economic } \\
\text { level }\end{array}$ & $\begin{array}{l}\text { Social } \\
\text { capital of } \\
\text { the macro- } \\
\text { economic } \\
\text { level }\end{array}$ & $\begin{array}{l}\text { part of the profit } \\
\text { generated by growing } \\
\text { confidence in the } \\
\text { global economic } \\
\text { system } \\
\text { part of the profit } \\
\text { generated by the } \\
\text { creation of a local } \\
\text { institutional } \\
\text { environment }\end{array}$ & $\begin{array}{l}\text { differences in } \\
\text { access to the } \\
\text { international } \\
\text { market } \\
\text { differences in the } \\
\text { institutional } \\
\text { environment }\end{array}$ & $\begin{array}{l}\text { the exclusive right to use the } \\
\text { resources of a particular } \\
\text { country in world economic } \\
\text { relations as a global benefit } \\
\text { belonging to a given } \\
\text { environment }\end{array}$ \\
\hline $\begin{array}{l}\text { Income from } \\
\text { the social } \\
\text { capital }\end{array}$ & $\begin{array}{l}\text { Social } \\
\text { capital of } \\
\text { the meso- } \\
\text { economic } \\
\text { level }\end{array}$ & $\begin{array}{l}\text { part of the profit } \\
\text { generated by reducing }\end{array}$ & $\begin{array}{l}\text { differences in } \\
\text { resource efficiency }\end{array}$ & $\begin{array}{l}\text { specification of rights to } \\
\text { resources as a result of } \\
\text { belonging to a particular } \\
\text { group }\end{array}$ \\
\hline $\begin{array}{l}\text { accumulation } \\
\text { at the meso- } \\
\text { economic } \\
\text { level }\end{array}$ & Social & $\begin{array}{l}\text { transaction and } \\
\text { production costs, the } \\
\text { growth of reputation }\end{array}$ & $\begin{array}{l}\text { differences in } \\
\text { access to } \\
\text { resources: } \\
\text { informational, } \\
\text { financial, } \\
\text { commercial }\end{array}$ & \\
\hline $\begin{array}{l}\text { Income from } \\
\text { the social } \\
\text { capital } \\
\text { accumulation } \\
\text { at the micro- } \\
\text { economic } \\
\text { level }\end{array}$ & $\begin{array}{l}\text { capital of } \\
\text { the micro- } \\
\text { economic } \\
\text { level }\end{array}$ & $\begin{array}{l}\text { part of the profit } \\
\text { generated by reducing } \\
\text { transaction costs } \\
\text { part of the profit } \\
\text { generated by the use of } \\
\text { personal qualities, } \\
\text { social relationships, } \\
\text { position in the group }\end{array}$ & $\begin{array}{l}\text { differences in } \\
\text { resources available } \\
\text { to the group } \\
\text { differences in the } \\
\text { availability of } \\
\text { personal } \\
\text { relationships, } \\
\text { education }\end{array}$ & $\begin{array}{l}\text { specification of rights to } \\
\text { resources as a result of } \\
\text { belonging to the group } \\
\text { the exclusive right to form } \\
\text { social communication skills, } \\
\text { etc. }\end{array}$ \\
\hline
\end{tabular}

Measuring investments in social capital in Ukraine is seriously complicated by the systemic and institutional incompetence of this type of reality, as well as:

the unformed single concept of the social investment: absence of well-established rules and customs of the classification of certain financial investments as social investments related to the main business activity (for example, investment in personnel);

mostly a haphazard approach to the social investment;

a significant difference in goals and motivations that different centers of influence face in the enterprise; the imperfection of the rules of accounting, including managerial accounting, in particular, for social programs to support their employees and external programs;

the absence of generally accepted standards for public social reporting of enterprises.

\subsection{Methodology of social investment assesing}

In the world practice, the Global Reporting Initiative, 2008 in [10] standard, established in 1997, prevails; it is aimed to establish common approaches to enterprise reporting and includes indicators of social and environmental policies of enterprises. 
Methodologically, this problem is based on the construction of the so-called social investment index. To form a systemic picture in the field of investment in social sphere at the mesoeconomic level, for example, it is appropriate to consider social investment in two interrelated aspects: quantitative and qualitative.

A quantitative aspect involves a direct assessment of the financial costs of enterprises in the region for social programs and initiatives. The characteristic of this aspect can be a quantitative generalization index of investments in social capital and a system of partial indices. These indicators suggest the diagnosis of both absolute and relative values of the amount of money prepaid in the region by enterprises for social programs.

In addition to the quantitative assessment of the social investment process it is necessary to consider a qualitative component of this process. The fact is that the funds advanced for social programs are only one of the characteristics of a socially responsible enterprise's activity. Quantitative indices answer the question of how much money is invested. However, the question of how the investment in social sphere is made is not less important. At this time, many Ukrainian enterprises began to implement their social programs on the basis of a comprehensive strategy. They include in the programs the main organizational elements of the investment process.

The qualitative aspect is related to the assessment of the degree of completeness and complexity of the investment process. The characteristic of this aspect is carried out with the help of a qualitative index of the investment in social capital. In fact, this index allows determine the degree of the investment in social capital diversification, the level of organizational support and information provision of social activity of enterprises. Unlike the quantitative index of social investments, which creates a picture of the scale of the phenomenon, the qualitative index of social investments is intended to assess the degree of complexity and completeness of a phenomenon such as corporate social responsibility. The idea of the given index consists in the account of the fact of presence (or absence) of positive parameters at the enterprise-respondent. The presented index system allows not only to measure investments in social capital, but also to analyze the nature of the Ukrainian entrepreneurs, the state and society interaction. It should be noted, in particular, that the developed system of social investment indices aims to form objective representations about the social orientation of Ukrainian entrepreneurship. Thus, the methodical approach to assessing investments in social capital at the micro-, meso- and macroeconomic level is carried out in the following sequence (Fig. 1).

In the literature [2] there are different methods which possible to use for investment assesment. In the paper, the method of taxonomy is proposed for calculating the qualitative and quantitative estimation of social investments into enterprise / region / country activity. The advantage of this method is the ability to standardize quantitative or qualitative indicators that describe the properties of a particular object in a generalized measurement system [22] (Plyuta, 1980).

That is, the result of the investments' assesment in the social activity by the levels of the economic system will be determined as the integral indicator of qualitative and quantitative parts of investments in social sphere which is based of the justified system of its partial indicators of the socio-economic state for a certain level of the economic system. This will allow formulate a policy of social development in the future.

\section{Conclusion}

The conducted analysis confirms the urgency of the issue of overcoming the shortage of social capital in the Ukrainian economy. One of the directions of solving this problem is a social investment, the methodical provision of which in scientific research will allow to implement a comprehensive approach to ensuring the growth of social capital at different levels of the economy, and in the practice of management will allow to have a methodical basis for institutional planning, developing economic development programs, eliminating social capital dysfunctions in its development.

As a result of the research, a system of classification of income types from the social capital accumulation was built, and a conceptual approach to a comprehensive system for assessing social investment at the micro-, meso- and macroeconomic level was proposed. Its complexity is in using both quantitative and qualitative assessment, both generalized indicators and a panel of partial indicators. All this will allow effectively identify the main problems of the investment in social capital management and ways to overcome it. Further research should be aimed at creating an effective mechanism for the social capital accumulation and developing recommendations for opportunities for its further growth. 


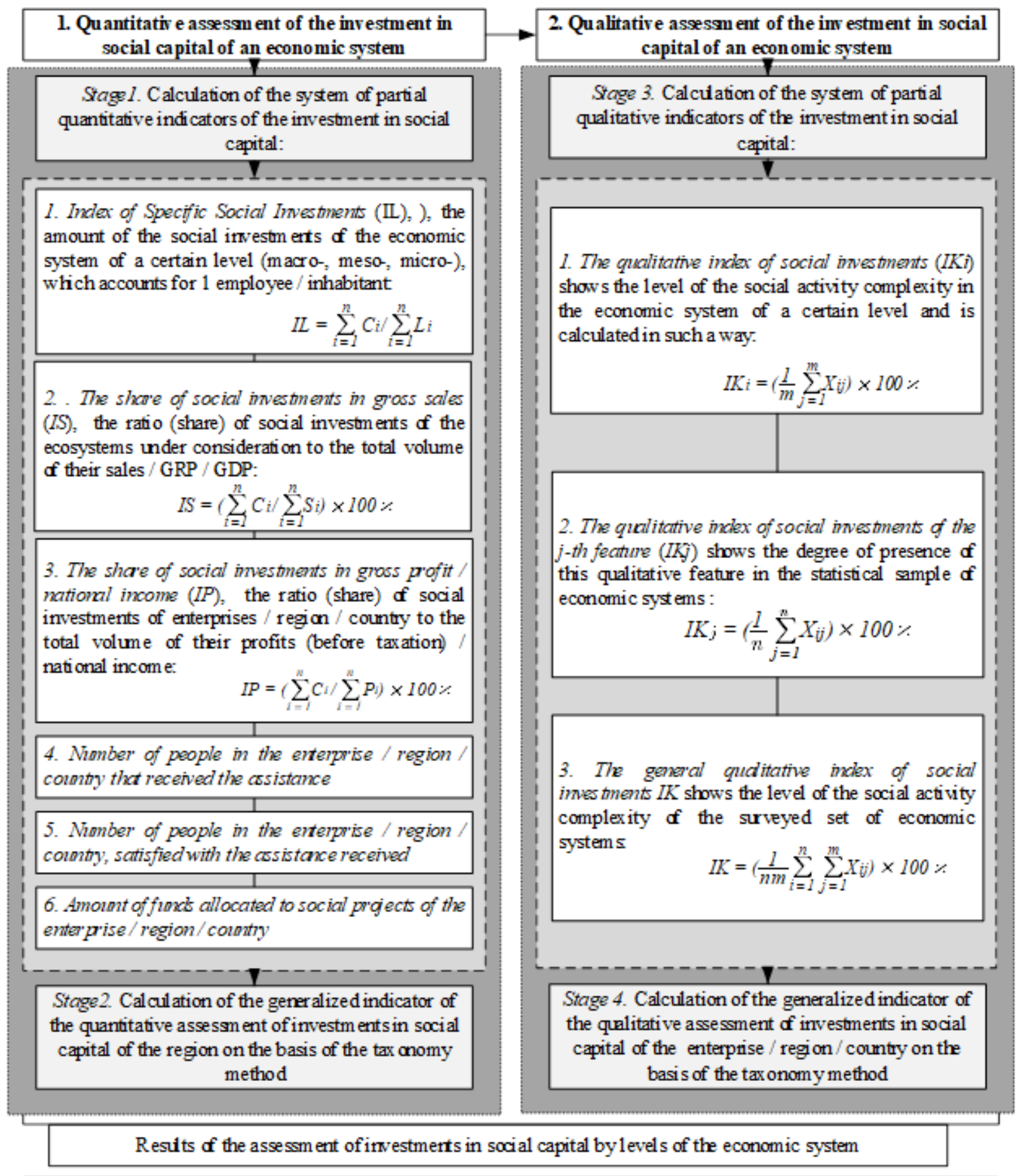

Legend

$C_{i}$ - the volume of social investments in the i-th economic system (induding voluntary and compul sory ex penditure on social program s); $L_{i}$ - average number of employees of the $i$-th enterprise / residents of the region / cauntry, $S_{i}-$ gross sales volume of the i-th enterprise / GRP of the region / GDP of the country, $P_{i}-g$ oss $p$ dit of the i-th enterprise / GRP of the region/GDP of the country, $X_{i j}$-bodean variable that takes the value 1 if the $\mathrm{j}$-th feature is present in the i-th economic system, and is 0 if this feature is missing $m-$ number of features on which social activity is assessed in economic syst ems; $n$ - number of economic system s involved in the survey

Figure 1. A comprehensive system of assessing social investment at macro-, meso- and microeconomic levels 


\section{Acknowledgement}

The Authors express their gratitude to the Management of Simon Kuznets Kharkiv National University of Economics, Kharkiv, Ukraine, for providing necessary facilities to complete this study successfully.

\section{References}

[1] V. Babenko, et al., "Research into the process of multi-level management of enterprise production activities with taking risks into consideration," Eastern-European Journal of Enterprise Technologies, Vol. 1, No 3 (91), pp. 4-12, 2018. DOI: 10.15587/1729-4061.2018.123461.

[2] V. Babenko, et al., "Aspects of program control over technological innovations with consideration of risks", Eastern-European Journal of Enterprise Technologies, vol. 3/4 (93), pp. 6-14, 2018. DOI: 10.15587/1729-4061.2018.133603.

[3] P. Bourdieu, Sotsiologiya politiki. Moskva: Socio-Logos, 1993. (in Russian)

[4] P. Bourdieu and M. Granovetter, Forms of Capital. The Sociology of Economic Life, 2nd Ed. Boulder: Westview Press, 2001.

[5] A. A. Bova, Sotsialnyi kapital v Ukraini: dosvid empirychnoho doslidzhennia. 2003. (http://soskin.info/ea/2003/5/20030517.html). (in Ukrainian)

[6] J. S. Coleman, Foundations of social theory. Belknap of Harvard University Press, Cambridge. 1990.

[7] F. Fukuyama, Sotsial'nyy kapital. Kul'tura imeet znachenie. Kakim obrazom tsennosti sposobstvuyut obshchestvennomu progressu. Moskva: Moskovskaya shkola politicheskikh issledovaniy, 2002. (in Russian)

[8] F. Fukuyama, (2004). Doverie: sotsial'nye dobrodeteli i put' k protsvetaniyu. ZAO NPP "Ermak", Moskva.

[9] E. L. Glaeser, et al., An Economic Approach to Social Capital. 2012. (https://onlinelibrary.wiley.com/doi/abs/10.1111/1468-0297.00078).

[10] GRI, Global Reporting Initiative standard. 2018. (https://www.globalreporting.org/standards).

[11] F. Güzel , et al., "Sovereign Wealth Funds: A Comparison of the Turkish Sovereign Wealth Fund with the World Samples", Periodicals of Engineering and Natural Sciences, Vol. 5, No. 2, pp. 165-175, June 2017. DOI: 10.21533/pen.v5i2.107.

[12] Z. I. Halushka, "Sotsialni investytsii pidpryiemstv yak instrument sotsialnoi vidpovidalnosti biznesu," Visnyk Chernivetskoho torhovelno-ekonomichnoho instytutu. Seriia: Ekonomichni nauky, 1, pp. 193-198, 2012. (in Ukrainian)

[13] O. Hrishnova and N. Polyviana, "Sotsialnyi kapital: sutnist, znachennia, vzaiemozviazok z inshymy formamy kapitalu," Ukraina: aspekty pratsi, 3, pp. 19-24, 2009. (in Ukrainian)

[14] I. Yu. Hryshova and T. S. Shabatura, "Sotsialni investytsii yak instrument realizatsii sotsialnooriientovanoho biznesu", Visnyk Sumskoho natsionalnoho ahrarnoho universytetu. Seriia: Ekonomika i menedzhment, 4, pp. 183-186, 2014. (in Ukrainian)

[15] H. I. Hrytsaienko and M. I. Hrytsaienko, "Sotsialni investytsii v sotsialnyi kapital", Biznes-inform, 1, pp. 188-194, 2018. (in Ukrainian)

[16] I. Klympush-Tsyntsadze, Ramkova prohrama partnerstva mizh Uriadom Ukrainy ta UN na 2018-2022 rr. nadzvychaino vazhlyva dlia pokrashchennia sytuatsii na Skhodi. 2017. (https://www.kmu.gov.ua/ua/news/250380857). (in Ukrainian)

[17] S. Knack, "Social capital and the quality of government: evidence from the States," American Journal of Political Science, 16(4), pp. 772-783, 2002.

[18] V. V. Kuzhel, "Sotsialna polityka ta sotsialni investytsii pidpryiemstv ahroprodovolchoi sfery," Ekonomichnyi forum, 1, pp. 286-294, 2015. (in Ukrainian)

[19] L. S. Melnychuk, "Sutnist ta znachennia sotsialnykh inestytsii," Hlobalni ta natsionalni problemy ekonomiky, 11, pp. 434-437, 2016. (in Ukrainian)

[20] V. I. Nadraha, "Teoretychni aspekty finansuvannia sotsialnykh investytsii," Finansy Ukrainy, 2, pp. 7078, 2014. (in Ukrainian)

[21] R. Patnem, Chtoby demokratiya srabotala. Moskva: Ad Marginem, 1996. (in Russian)

[22] V. Plyuta, Sravnitel'nyy mnogomernyy analiz v ekonomicheskikh issledovaniyakh. Metody taksonomii i faktornogo analiza. Moskva: Statistika, 1980. (in Russian)

[23] P. N. Shikhirev, "Priroda sotsial'nogo kapitala: sotsial'no-psikhologicheskiy podkhod," Obshchestvennye nauki i sovremennost', 2, pp. 20-24, 2003. (in Russian) 
[24] The World Bank, Year in review: 2018 in 14 charts. 2018. (http://www.worldbank.org).

[25] O. V. Veretennykova, "Instytut sotsialnoho investuvannia: sutnisni oznaky ta funktsionalnyi proiav u svitli pohliadiv klasykiv ekonomichnoi teorii," Vcheni zapysky universytetu "KROK". Seriia: Ekonomika, 33, pp. 11-17, 2013. (in Ukrainian)

[26] K. B. Voloshchuk, "Kharakterystyka intelektualnykh i sotsialnykh skladovykh innovatsiinoinvestytsiinoho potentsialu ahropromyslovykh pidpryiemstv," Zbirnyk naukovykh prats Podilskoho derzhavnoho ahrarno-tekhnichnoho universytetu, 21, pp. 117-122, 2013. (in Russian)

[27] S. Ulubeyli, et al., "Comparative Life Cycle Costing Analysis of Green Roofs: The Regional Aspect", Periodicals of Engineering and Natural Sciences, Vol.5, No.2, pp. 136-144, June 2017.

[28] B. O. Yazliuk, "Fundamentalni ta prykladni ekonomichni mekhanizmy pidpryiemstv pry realizatsii sotsialnykh investytsii yak osnova innovatsiinoho rozvytku derzhavy," Ekonomichnyi analiz, 2(18), pp. 280-285, 2014. (in Ukrainian) 